\title{
Idéias antiescravistas da Ilustração na sociedade escravista brasileira
}

Antonio Penalves Rocha Universidade de São Paulo

\section{RESUMO}

Este artigo pretende examinar como as idéias antiescravistas da Ilustração foram assimiladas por alguns letrados brasileiros do começo do século XIX para mostrar a especificidade que elas adquiriram na sociedade escravista brasileira.

Palavras-chave: Escravidão, Ilustração, Antiescravismo Brasileiro.

\begin{abstract}
This article intends to examine how the antislavery ideas of the Enlightnment were assimilated by some Brazilian men of letters of the early nineteenth century to show the specificity they acquired in the Brazilian slave society.

Keywords: Slavery, Enlightenment, Brazilian Antislavery
\end{abstract}

Rejeito o testemunho [sobre a condição dos escravos] dos que defendem a causa da escravidão, dos que propõem amenizá-la pelas leis, quando vejo que eles têm ou esperam ter empregos dados pelos proprietários, ou que eles próprios têm escravos, ou que, enfim, foram protetores ou cúmplices da tirania nas colônias.

(Condorcet)

A onda de mudanças que varreu o Ocidente a partir do início dos Tempos Modernos não suprimiu as estruturas de antigas formas de organização da produção, baseadas no emprego do trabalho forçado. Mesmo no século XVIII, uma instituição multimilenar - a escravidão - e outra multissecular - a servidão - exibiam vigor, submetendo milhões de es- 
cravos negros nas colônias americanas e servos espalhados pela maior parte da Europa.

Até meados desse mesmo século, essas instituições foram consideradas como partes constitutivas da natureza das sociedades. A partir daí, no entanto, tornaram-se alvo de veementes ataques de alguns escritores da Ilustração, que incorporavam inclusive críticas de grupos religiosos ingleses - quacres e evangélicos - à escravidão negra; neles se encontram as bases de um ideário que desempenhou um papel histórico relevante por ter fundamentado a repulsa do mundo contemporâneo a qualquer espécie de trabalho forçado, legitimando, conseqüentemente, o estabelecimento universal das sociedades baseadas no emprego do trabalho livre.

Com efeito, a eficácia histórica desse ideário foi de tal ordem que movimentos abolicionistas e estadistas da América e da Europa usaram seus princípios, nos séculos XVIII e XIX, para desmantelar as últimas sociedades escravistas da história, ou para eliminar os remanescentes do trabalho feudal. $\mathrm{O}$ combate simultâneo à escravidão e à servidão deveuse, a princípio, a uma identificação entre ambas as instituições no vocabulário, pois, como demonstrou Jean Ehard, "o século XVIII nem sempre distinguia escravidão e servidão com clareza" ${ }^{1}$. É isso que se vê na afirmação de Adam Smith de que um tipo de escravidão "ainda subsiste na Rússia, Polônia, Hungria, Boêmia, Morávia, e outras partes da Alemanha. É somente nas províncias do oeste e do sudoeste da Europa, que ela vem sendo gradualmente abolida”2 ${ }^{\prime 2}$ ou na censura de Raynal a Montesquieu, dado que este último havia dito que cristianismo e escravidão eram incompatíveis: "na Alemanha católica, na Boêmia, na Polônia, países muito católicos, o povo é ainda escravo" ${ }^{\prime 3}$. Mesmo na segunda década do século XIX, Henri Storch, um economista russo, num livro publicado em francês e comentado por J.-B. Say, referia-se à "escravidão de corvéia" na Rússia, embora reconhecesse que havia diferença "entre um escravo russo e um negro vendido nas colônias" ${ }^{\prime 4}$.

Há testemunhos de que este mesmo ideário, principalmente nos termos em que havia sido formulado na Ilustração francesa, foi trazido para o Brasil - a segunda maior sociedade escravista da América ${ }^{5}$-, nas primeiras décadas do século XIX, principalmente por estudantes brasileiros que tinham freqüentado universidades européias, como as de Coimbra 6 , Montpelier, Edimburgo e Estrasburgo.

A presença de estudantes brasileiros nas universidades européias dos fins do século XVIII e início do XIX e o transporte das idéias ilustradas para o Brasil já receberam a atenção de historiadores como Maria Odi- 
la da Silva Dias e de Kenneth Maxwell?. Silva Dias analisou a aquisição de conhecimentos científicos por estudantes brasileiros na Europa e suas observações so bre o Brasil com as lentes das ciências da natureza; Maxwell mostrou de que forma estudantes brasileiros usaram idéias políticas e sociais da Ilustração para idealizar o império luso-brasileiro. Certamente esses dois historiadores não deram atenção ao transporte de idéias antiescravistas da Ilustração para a sociedade escravista brasileira porque examinaram outros objetos, embora Maxwell tenha colocado a escravidão em cena ao lhe atribuir um papel relevante na redefinição da ordem que governava as relações entre Portugal e Brasil. De resto, a questão do transporte das idéias antiescravistas ainda não recebeu da historiografia brasileira a condição de objeto de análise privilegiado.

A principal razão de ser deste trabalho é a tentativa de elevá-lo a essa condição. Para realizar tal empreitada, serão examinados os textos tidos como pioneiros ${ }^{8}$ da crítica à escravidão no Brasil, escritos entre os anos de 1817 e fins da década de 1820, e publicados na década de 1820, exceto um deles, que só veio a lume em 1851. Há, decerto, uma defasagem temporal entre a Ilustração e a data dessas publicações o que, no entanto, não representa uma ameaça aos propósitos do exame, pois as idéias antiescravistas dos princípios do século XIX não romperam com as do século anterior, mas desenvolveram-nas.

Os textos referidos são os seguintes: Memória sobre a necessidade de abolir a introdução de escravos africanos no Brasil, sobre os modos e condições com que esta abolição se deve fazer e sobre os meios de eme diar a falta de braços que ela pode ocasionar (1821) de João Severiano Maciel da Costa; Memórias economo-políticas (1822) de Antonio José Gonçalves Chaves; Representação à Assembléia Geral Constituinte e Le gislativa do Império do Brasil sobre a escravatura (1825) de José Bonifácio de Andrada e Silva e "Da Liberdade do Trabalho" (1851) de José da Silva Lisboa'.

Do mesmo modo que a transposição de algumas das idéias da Ilustração para o Brasil já foi bem examinada, também esses textos são familiares à historiografia brasileira, tendo servido de fontes para a análise da escravidão brasileira do período em que foram escritos, ou para explicar aspectos das relações entre a escravidão e a constituição do Estado brasileiro, ou ainda para estudar o desenvolvimento do antiescravismo no Brasil $^{10}$. Enfim, não há ineditismo algum no exame do processo de transposição de idéias ilustradas para o Brasil nem tampouco no uso desses textos como documentos históricos. 
Mas, está tudo para ser feito no que diz respeito à relação entre essa transposição e essas fontes, sendo que ela guarda informações sobre o perfil das primeiras críticas feitas à escravidão no Brasil. Ou seja, se estas fontes forem examinadas por outros métodos e submetidas a outros questionamentos será possível dar os primeiros passos para conhecer algo que não foi observado até hoje na historiografia: a especificidade que as idéias antiescravistas geradas pela Ilustração européia adquiriram na sociedade escravista brasileira.

No que diz respeito à difusão dessas idéias nessa sociedade, há que se considerar que a população brasileira dos princípios do século XIX era predominantemente iletrada, o que vale dizer que os letrados formavam uma minoria numericamente inexpressiva. Deste modo, não faria sentido algum tentar examinar a propagação das mesmas, que, de resto, não tiveram nenhum efeito prático imediato e seus prováveis leitores foram certamente outros poucos letrados.

Por outro lado, esses textos permitem compreender o ponto máximo que o antiescravismo pôde alcançar, na época, dentro dessa sociedade. Além do mais, desde a Vinda da Família Real ao Brasil, os letrados passaram a participar dos quadros da buro cracia governamental, posição esta que mantiveram depois da Independência, isto é, participavam do único grupo capaz de promover mudanças institucionais na escravidão; inversamente, os donos de escravos, em geral, estavam acomodados à ordem escravista e empenhados em mantê-la.

Para levar a cabo esse exame, serão inventariados, em primeiro lugar, os autores europeus citados nos textos dos brasileiros, o que permitirá não só comprovar que fizeram parte do contexto do antiescravismo da Ilustração, como também conhecer suas fontes doutrinárias; em seguida, serão apresentados os principais elementos da crítica dos brasileiros à escravidão e as medidas práticas que propuseram para combatê-la. Estes dois últimos itens fornecerão dados que serão confrontados com as linhas gerais do antiescravismo da Ilustração francesa, pois, como se sabe, Portugal e Brasil, dos fins do século XVIII e início do XIX, estavam dentro da esfera de influência da cultura letrada francesa, além de os mais importantes textos ingleses que condenavam a escravidão terem sido traduzidos, a partir dos fins da década de 1780, pela Sociedade dos Amigos dos Negros da França ${ }^{11}$. É por esse caminho que se tentará apreender a especificidade das primeiras manifestações antiescravistas no Brasil. 


\section{I - O ANTIESCRAVISMO DOS ILUSTRADOS NOS TEXTOS BRASILEIROS}

Nada se sabe sobre o aparecimento de um antiescravismo genuinamente brasileiro durante a segunda metade do século XVIII, período este das primeiras manifestações de condenação da escravidão principalmente na França, na Inglaterra e nos Estados Unidos. Isso não impede, no entanto, supor que se houve alguma manifestação contra a escravidão gerada internamente a sua difusão deve ter sido inexpressiva, pois, além das limitações impostas pela censura, a impressão tipográfica era proibida no Brasil; não bastassem estas restrições, Estado, Igreja e senhores estavam interessados em preservar a escravidão, e se empenhavam em bloquear a expressão de idéias que ameaçassem a ordem vigente.

A Análise sobre a Justiça do Comércio de Resgate de Escravos da Costa da Africa de Azeredo Coutinho, escrita nos últimos anos do século XVIII e publicada em Londres e em Lisboa, respectivamente em 1798 e em 1808, participou dessa ordem ao defender a legitimidade do tráfico negreiro e, portanto, da escravidão. Por meio dela, Azeredo Coutinho, conhecedor das idéias européias da época ${ }^{12}$, reagiu energicamente à condenação do tráfico em nome do direito natural, tal como estava sendo feita por pensadores franceses desde a publicação, na Enciclopédia , dos artigos "Escravidão" e "Tráfico de negros", ambos escritos por de Jaucourt.

Ao contrário de Azeredo Coutinho, os primeiros escritores brasileiros que criticaram a escravidão observaram a sociedade escravista a partir de princípios elaborados em outro tipo de sociedade. Sendo assim, o arrolamento dos autores europeus citados pelos brasileiros poderá evidenciar a ligação entre estes últimos e o antiescravismo da Ilustração. Este mesmo procedimento fornecerá também pistas sobre o caráter do antiescravismo dos brasileiros, dado que as citações indicam as fontes de inspiração das concepções dos brasileiros sobre o assunto.

Antonio José Gonçalves Chaves, cujo texto ocupa cronologicamente o primeiro lugar na série ${ }^{13}$, citou Raynal e Adam Smith. Do primeiro, extraiu um trecho da sua "História política" (sic), no qual o padre francês associou o caráter nacional do colonizador com o tratamento dado ao escravo nas colônias americanas. Para Raynal, "o português faz deles [escravos] instrumentos de seus deboches", e Gonçalves Chaves recusou tal comentário sob o argumento de que havia nele "parcialidade manifesta”"14, pois são maltratados em qualquer nação. Além de Raynal, Gonçalves Chaves citou também "um Economista", que se reconhece facilmente como Adam Smith, por se tratar de uma conhecida passagem da Riqueza das Nações que contém uma das suas críticas à escravidão; de fato, para 
sustentar seu argumento de que o uso de escravos causava danos econômicos, reproduziu palavras do economista escocês, segundo as quais o escravo consome o mais que pode e trabalha o menos que pode ${ }^{15}$.

O eixo do texto de Gonçalves Chaves apoiava-se, no entanto, num outro, escrito por um membro da Academia Real de Ciências de Lisboa, Francisco Soares Franco, que, em 1820, publicara o Ensaio sobre os Me lhoramentos de Portugal e do Brazil em Lisboa. A doutrina contida no "Quarto Caderno" deste livro, dedicada a um exame intitulado "Da População, e Agricultura no Brazil”"16, foi vivamente recomendada por Chaves, que reproduziu um longo trecho da mesma.

Maciel Severiano da Costa citou a Apologie de B. de las Casas de Grégoire; acusou Raynal, afirmando que "todo mundo sabe" dos seus "interesses" no tráfico negreiro, e da sua ligação com empresas que dele participavam em Nantes e Marselha; recorreu a Montesquieu para confirmar a idéia de que o trabalho livre pode ser aplicado em todos os setores da economia adotou a explicação dada por Page no seu Tratado de Econo mia Política e Comércio das Colônias sobre o significado do plano inglês para acabar com o tráfico; assegurou que Turgot, Steuart, Adam Smith, Herrenschwand, Bentham, e Ganilh, consideravam o trabalho "menor e menos lucrativo nas mãos dos escravos", ao passo que Jean-Baptiste Say "pensa o contrário"17.

José Bonifácio de Andrada e Silva citou apenas Pierre Poivre ${ }^{18}$, autor das Viagens de um Filósofo ou Observações sobre os Costumes e as Artes dos Povos da África e da Ásia, escrito em 1750 e publicado em 1768. Este livro de Poivre teve um papel importante na história da Economia Política francesa, tanto que, como afirmou Weulersse, os fisiocratas o consideravam, pelo valor que atribuiu à agricultura, um dos precursores da fisiocracia, ou então como "um dos seus discípulos avant la lettre "19. Esse mesmo livro foi resenhado no primeiro artigo antiescravista escrito por Du Pont de Nemours no periódico oficial da Fisiocracia - as Efemérides do Cidadão ou Biblioteca Racional das Ciências Morais e Políticas （t.VI, 1768); além disso, Du Pont também publicou, em 1768, uma biografia intitulada Notice sur la vie de M. Poivre. A importância de Poivre para os termos da condenação à escravidão feita pelos fisiocratas assumiu uma tal proporção que estes últimos adotaram suas observações sobre a baixa quantidade de cana-de-açúcar produzida pelos escravos e o alto custo dessa produção, posição esta compartilhada por José Bonifácio.

Afora a importância que as opiniões de Poivre sobre a escravidão tiveram na história do pensamento econômico, Seeber colocou um Discur - 
so de sua autoria, provavelmente escrito em 1767, em primeiro lugar na lista dos textos franceses do século XVIII que apresentaram soluções práticas para a questão da escravidão. Poivre recomendava que, se "o mal está feito", deveria haver estrita observância das leis, neste caso as leis do Code Noir, para reduzir os estragos causados pela escravidão. Por isso mesmo, os senhores deveriam instruir seus escravos no cristianismo, encorajar os casamentos entre eles, alimentá-los e vesti-los adequadamente e tratá-los com humanidade; só assim, dizia Poivre, eles "sempre servirão bem seus senhores, durante a paz e durante a guerra (...) Seus filhos considerarão a casa do senhor como a casa paternal, e a ilha [a colônia] como sua pátria” 20.

No artigo de José da Silva Lisboa, "Da Liberdade do Trabalho" nas dois autores da Ilustração são citados: Adam Smith e Montesquieu. O alicerce do artigo foi dado pela Riqueza das Nações, mais precisamente por um princípio formulado por Adam Smith, segundo o qual há um "esforço natural de cada homem para melhorar a sua própria condição", sendo que os interesses pessoais coincidem com os coletivos. Para Silva Lisboa, era impossível a realização deste princípio numa sociedade que emprega o trabalho escravo, pois o escravo é reduzido à condição de máquina, "não esperando melhoria [...], nem podendo adquirir propriedade"; resulta daí que falta ao escravo motivação para se empenhar nas atividades produtivas, o que torna a escravidão nociva à "opulência e civilização". Não bastasse isso, Silva Lisboa reproduziu também a maioria dos argumentos de Adam Smith contra a escravidão: a administração do escravo é mais cara do que a do homem livre, pois com a escravidão não há frugalidade, tampouco parcimônia; os escravos raramente inventam máquinas, pois podem ser acusados de preguiçosos pelos seus senhores, etc.

Adam Smith emprestou algumas idéias de Montesquieu sobre a escravidão e as reproduziu na Riqueza das Nações. Há uma delas que Silva Lisboa citou como sendo de autoria de Adam Smith: trata-se da idéia de Montesquieu de que a origem da escravidão residia no orgulho. Uma outra, também citada por Silva Lisboa, refere-se à superioridade das minas da Hungria que empregavam o trabalho livre, em comparação com as da Turquia que empregavam o trabalho escravo; desta vez o autor brasileiro a atribuiu ao seu verdadeiro autor. Além disso tudo, Silva Lisboa certamente se inspirou no Livro XV de O Espírito das Leispara relacionar a escravidão negra das colônias americanas com a "inculcada necessidade de um clima ardente", e adotou também a doutrina da mitigação da escravidão de Montesquieu, que será apresentada mais adiante. 
A citação desses autores europeus, cuja excelência já era reconhecida desde a época em que publicaram suas principais obras, mostra que uns poucos brasileiros haviam aprendido a ver a escravidão com o olhar dos ilustrados europeus e a eleger alguns princípios para condená-la. A primeira comprovação disto encontra-se nas citações de Montesquieu, ausentes apenas no texto de Andrada e Silva.

Na França, até os meados do século XVIII, a crítica à escravidão fora feita por um número reduzidíssimo de pensadores, como Bodin, Le Clerc e Bernard, cujas idéias aliás não tiveram desdobramentos ulteriores; ao lado dela, havia também a reprovação difusa de que a satisfação do luxo dos europeus ocorria às custas do sofrimento dos escravos negros. Este quadro, no entanto, sofreu uma mudança radical com Montesquieu, que, como afirmou Brion Davis, "mais que qualquer outro pensador, [colocou] a escravidão na agenda da Ilustração européia" ${ }^{\prime 2}$. Isto porque, $\mathrm{O}$ Espínito das Leis, de 1748, de uma forma que até então não havia sido feita, condenou a escravidão sob os argumentos de que era uma instituição incompatível com a moral e, portanto, uma violação do direito natural, contrária ao espírito da monarquia, incoerente com o direito civil, inconciliável com o cristianismo e com um rendimento inferior ao do trabalho livre. Estas mesmas idéias foram ordenadas por de Jaucourt, que as veiculou nos artigos "Escravidão" e "Tráfico negreiro" ${ }^{23}$ do maior sucesso editorial do século, a Enciclopédia, dirigida por D’Alembert e Diderot.

Além de Montesquieu, praticamente todos os escritores brasileiros usaram princípios antiescravistas da Economia Política. Andrada e Silva citou apenas Poivre, mas mostrou conhecimento desses mesmos princípios; Gonçalves Chaves e Silva Lisboa apoiaram-se em Adam Smith, e Severiano Costa citou uma série de economistas franceses da Escola Clássica, que seguiram as linhas das críticas de Adam Smith em relação à escravidão. A adesão dos brasileiros à crítica econômica da escravidão liga-se ao fato de que ela era reconhecida como a única condenação propriamente científica desta instituição. Sua formulação inicial foi obra dos fisiocratas, isto é, apareceu no momento mesmo em que Economia Política dava seus primeiros passos para adquirir existência autônoma; ampliando a crítica, e revestindo-a de um caráter diferente daquele que lhe fora imposto pelos fisiocratas, Adam Smith, assegurou a ela um espaço no conhecimento econômico.

Em suma, ao usar principalmente princípios elaborados por Montesquieu e pelos economistas políticos, os brasileiros expunham, em ge- 
ral, suas ligações com o antiescravismo da Ilustração, e, ao mesmo tempo, a adesão, em particular, a certas doutrinas para orientar mudanças da escravidão brasileira, como se verá mais adiante.

\section{O TEOR DA CRÍTICA DOS BRASILEIROS À ESCRAVIDÃO}

A existência da escravidão foi assegurada pela legitimidade que lhe conferiu uma rede de idéias tecida desde a Antigüidade. Sendo assim, ela era reconhecida como um elemento constitutivo natural das sociedades, atado pelos fios dessa mesma rede aos demais elementos - política, economia, estrutura social, religião e cultura.

A condenação da escravidão, por outro lado, resume-se ao resultado de um processo de negação da sua legitimidade. Tal processo, contudo, não nasceu de uma só penada, mas derivou de uma construção lenta e custosa, iniciada com o desatamento dos fios que prendiam a escravidão às demais instituições sociais; ou seja, para provar a sua ilegitimidade foi necessário demonstrar que a escravidão se opunha aos princípios do cristianismo, representava uma ameaça ao Estado, era economicamente nociva, violava o direito natural, etc. Foi necessário, em suma, desmontar a rede de idéias que a colocava no mesmo plano das demais instituições mediante a demonstração de que ela lhes era prejudicial, e, portanto, deveria ser substituída pelo trabalho livre. Esta operação de desmontagem principiou nos meados do século XVIII, ocupou todo o século XIX para, finalmente, alcançar seu ponto mais alto nos fins da primeira metade do XX com a Declaração dos Direitos Humanos.

No que diz respeito à sua forma, essa operação teve um caráter cumulativo e seus protagonistas foram especialistas em determinados campos do conhecimento ${ }^{24}$. Ou melhor, a partir dos meados do século XVIII, observando a escravidão como especialistas de um campo do conhecimento (jurídico, econômico, político, religioso, etc.), alguns homens dirigiram a ela uma série de críticas, aprovadas e apropriadas pelos contemporâneos. Assim, por exemplo, o reconhecimento da autoridade de Montesquieu como teórico social é um dos fatores que explica o sucesso da sua crítica, segundo a qual a escravidão era uma ofensa ao Direito das Gentes, ao Direito Civil e ao Direito Natural; mutatis mutandis , o mesmo vale para a crítica de Adam Smith, que a considerou como lesiva à economia, ou para a dos quacres que a julgaram incompatível com a caridade cristã, ou para a de alguns filó sofos franceses da Ilustração que a retrataram como uma ameaça ao Estado, ou ainda para as observações de viajantes europeus que relatavam a péssima condição de vida dos escra- 
vos nas colônias. De qualquer modo, ao mesmo tempo em que cada um desses protagonistas efetuava a crítica à escravidão, começava a desatar um dos fios da rede que a ligava a uma determinada instituição, trabalho este que prosseguiu de forma cumulativa pelo século XIX afora.

O volume formado por essas críticas especializadas ao longo da segunda metade dos setecentos permitiu, ainda nos fins do XVIII, não só a passagem da crítica filosófica para a ação política contra a escravidão, 0 que valer dizer, para a elaboração de programas abolicionistas, como também o aparecimento de obras de síntese, que articularam as opiniões antiescravistas especializadas, como, por exemplo, a que Benjamin-Sigismond Frossard publicou nos últimos anos do século XVIII: A causa dos escravos negros e dos habitantes da Guiné. Levada ao Tribunal da Justi ça, da Religião, da Política; ou História do tráfico e da escravidão dos negros; Provas da sua ilegitimidade, Meios de os libertar sem prejudicar nem as Colônias e nem os Colonos.

Nada disso, porém, ocorria no Brasil dos princípios do século XIX, quando aqui apareceram as primeiras manifestações antiescravistas. De fato, não havia na sociedade escravista brasileira nem autoridades intelectuais, nem tampouco abolicionistas, mas unicamente uns poucos letrados que publicaram textos que destacavam os males causados pela escravidão, baseando-se em princípios construídos por escritores europeus.

A lista dos autores por eles citados e a forma pela qual observaram certos aspectos da escravidão indicam que não lhes faltava atualização com o que fora publicado na Europa. Além disso, escreveram entre 1817 e fins da década de 1820, isto é, no meio de um período de aceleração das transformaçõ es institucionais da escravidão negra nas colônias americanas: revolta dos negros no Haiti, abolição da escravidão pelos quacres nos Estados Unidos, movimento das petições na Inglaterra, abolição da escravidão nas colônias francesas (1794), restauração da escravidão nas colônias francesas (1803), fim do tráfico negreiro nas colônias inglesas e nos Estados Unidos, proibição do tráfico ao norte do Equador pelo Congresso de Viena e início dos debates no Parlamento inglês sobre a abolição da escravidão nas colônias inglesas. Sendo assim, escreveram num tempo em que, à velocidade das transformações da escravidão na América, correspondia o aumento do volume de publicações antiescravistas na Europa; tinham, portanto, à disposição, uma vasta literatura antiescravista que dialogava com os autores da Ilustração.

A partir do contato com esta literatura, os brasileiros escreveram textos que apresentaram todos os termos da crítica à escravidão que conde- 
navam genericamente. Porém, destacaram e examinaram particularmente alguns dos seus efeitos deletérios, sendo que a valorização em particular de alguns destes efeitos em detrimento de outros derivou das suas preocupações reais como membros da elite de homens livres sobre o que havia de mais defeituoso na sociedade escravista, haja vista que não eram especialistas neste ou naquele campo do conhecimento.

É exatamente naquilo que definiram como os piores defeitos da escravidão que reside o teor da crítica de cada um deles; a localização deste teor fornecerá, portanto, dados para a compreensão da especificidade das idéias antiescravistas na sociedade escravista brasileira e dos propósitos desses críticos de nela intervir.

Nas Memórias economo-políticas de Gonçalves Chaves encontramse manifestações de compaixão do autor pela condição do escravo, em frases em que lamenta a "infeliz sorte dos escravos, e dureza dos proprietários", ou em que afirma que só mesmo a ausência de sensibilidade humana impediria de "tremer à vista da infeliz sorte dos pretos escravos". A escravidão, por sua vez, é caracterizada como um "escândalo da humanidade e da religião", ou "um crime que ofende essencialmente a Deus" ${ }^{25}$.

Suas observações, no entanto, não se limitam a essas de caráter compassivo. Depois de reafirmar que o "sistema da escravatura (...) é escandaloso à Religião de Jesus Cristo e Natural" e que este é um ponto "reconhecido por to do mundo", Gonçalves Chaves enunciou claramente o objeto da sua Memória: "tratarei unicamente de quanto [a escravidão] é prejudicial ao Estado"26. Para dissertar sobre o assunto, tomou como ponto de partida a mudança ocorrida no Império Português em 1808. Antes da Vinda da Família Real ao Brasil, interessava à monarquia portuguesa manter a escravidão na sua maior colônia. Mas, depois que a sede do Império foi trasladada para o Rio de Janeiro, o sistema tornou-se "ruinoso por qualquer modo que queiram considerar" e a existência de escravos tornou-se uma barreira para "dois essenciais ramos economo-políticos": a união de todos os indivíduos e a conciliação de todos os ânimos.

A escravidão, segundo Gonçalves Chaves, era nociva à economia ao impedir o crescimento da população e o aumento dos trabalhadores livres, pois estes se envergonhavam de trabalhar ao lado dos escravos. Assim, todas as atividades produtivas eram executadas pelo braço do escravo, e, como Adam Smith afirmara, o escravo trabalha pouco e come muito. Enfim, para Gonçalves Chaves, a escravidão bloqueava a prosperidade da agricultura e o nascimento da indústria. Do mesmo modo que a economia, a civilização e a moral também eram ofendidas pela escravidão, por- 
que ela impedia o aparecimento de "classes instruídas" e as crianças livres cresciam numa sociedade em que prevalecia a imoralidade.

O dano maior, contudo, era aquele que a escravidão causava à governabilidade: "temos de fato [uma guerra] com $3 / 4$ da nossa população", já que os escravos são verdadeiramente "inimigos internos". Este estado de coisas podia, segundo o autor, ser facilmente atestado pela situação em que se encontra a Bahia, onde continuamente arrebentam "expulções nigropolíticas", expressando o "terrível mal a que está sujeita qualquer nação que cai na imprudência de consentir entre si tão extraordinário número de escravos ${ }^{\prime 27}$. Do exemplo das revoltas na Bahia, o autor deduziu uma "regra infalível": "toda a nação será mais ou menos bárbara, segundo o maior ou menor número de escravos que tiver".

Em suma, a constituição do Estado está ameaçada pela escravidão na medida em que o governo "se vê na dura necessidade de cometer atos que não podem ter lugar em código escrito constitucional, civil ou criminal". O cupando o Brasil a posição de "cabeça da monarquia portuguesa", todo o resto do Império português corre perigo. De fato, caso o tráfico negreiro persista e continue aumentando o número de escravos, o Estado estará duplamente ameaçado: dada a disseminação da bárbarie no Brasil, estrangeiros poderão usurpar o Trono, e "os negros serão nossos escravos e nós escravos de qualquer governo", isto se "escaparmos ao iminente risco da desastrosa e tremenda catástrofe dos franceses na ilha de S. Domingos" ${ }^{28}$.

Como foi dito antes, Gonçalves Chaves apoiou-se em observações de Soares Franco, segundo as quais to dos os corpos morais devem concorrer para a "segurança e a prosperidade do Estado"2, sendo que, com a escravidão negra, era inviável a formação de uma nação no Brasil, mesmo porque não há um povo composto de diversos povos. E o risco maior, alertava Franco num texto reproduzido por Chaves, que aliás retomava pela segunda vez o mesmo assunto, era "o exemplo terrível de S. Domingos [que] deve estar patente aos olhos de todos os brasileiros (...)".

João Severiano Maciel da Costa, na sua Memória sobre a Necessida de de Abolir a Introdução dos Escravos Africanos no Brasil , também apresentou elementos de uma crítica humanitária à escravidão ao considerar que "o trabalho por escravos (...) ofende o direito da humanidade, faz infeliz uma parte do gênero humano" ${ }^{\prime 30}$.

Flexibilizou, no entanto, essas ponderações ao argumentar que o tráfico não é "tão ho rrível quanto pintam seus antagonistas". O mundo africano, segundo o autor, é governado pela barbárie, razão pela qual os 
negros "vegetam quase sem elevação sensível acima dos irracionais, sofrem cruel cativeiro e são vítimas dos caprichos dos seus déspotas". Por isto mesmo, o tráfico tem um efeito benéfico ao evitar "uma horrível carniçaria humana". No Brasil, continua Maciel da Costa, é verdade que os escravos de fato são maltratados por alguns senhores; mas, "também o é que as leis os punem por excessos criminosos, que estes fatos perdem-se na grande maioridade dos que praticam tantos outros senhores em favor de seus escravos, tratando-os como homens e olhando para eles como uma parte principal de suas fortunas, que ninguém é tão desatinado que deseje arruinar e perder". Em toda parte acham-se senhores que dispensam todos os cuidados necessários aos escravos "e até, conduzindo-se eles bem, os recompensam com a liberdade e os ajudam a viver". Enfim, para o autor, os "amigos da humanidade... têm visto os males dos cativeiro dos africanos na América por vidros de engrossar" ${ }^{\prime 31}$.

O seu texto atribui também à escravidão a condição de instituição nociva à economia, pois "paralisa a indústria, que nunca pode prosperar solidamente senão em mãos de gente livre" e, como já se viu acima, Severiano Maciel apoiou-se numa série de economistas europeus para tratar do assunto. No entanto, o problema central da escravidão para o autor, é de outra ordem: ao lançar "em perpétua guerra uns com os outros homens", põ e em "risco iminente e inevitável [...] a segurança do Estado com a multiplicação indefinida de uma população heterogênea, desligada de to do vínculo social e, por sua mesma natureza e condição, inimiga da classe livre”. Dada essa argumentação, tem-se a impressão de que Maciel da Costa também se apoiou nas formulações de Soares Franco, o que é reforçado pelo título que deu ao "Parágrafo terceiro" da sua Memória: "A introdução dos escravos africanos, indefinida quanto ao número deles e quanto ao tempo de sua duração, é contrária à segurança e prosperida de do Estado" (grifado por mim - APR). Ainda mais, Maciel da Costa, passando, ao que parece, Soares Franco para outras palavras, afirmou que o aumento do número de escravos com o tráfico negreiro estava se transformando num "raio (que) nos ameaça perpendicularmente sobre a cabeça", porque uma população majoritariamente negra - a "África transplantada no Brasil" - era "incompatível com os brancos, antes inimiga declarada". Seguindo este mesmo raciocínio, concluiu o texto se lisonjeando de ter demonstrado que "a abolição [da introdução dos africanos no Brasil] é necessária à segurança e prosperidade do Estado" ${ }_{32}$.

Dessa forma, via uma grande ameaça pesando sobre os brancos, que poderia se agravar se os escravos negros fossem contagiados pelas idéias 
de "liberdade e quimérica igualdade (...) das colônias francesas". Se isto realmente ocorresse, seria "a insurreição súbita, assoprada por um inimigo estrangeiro, estabelecido em nossas fronteiras e com um pendão de liberdade arvorado ante suas linhas". Não haveria como fazer frente a ela, fato este que João Severiano expressou por meio de uma pergunta: "que resistência faremos ao inimigo exterior estando a braços com o interior e composto de escravos bárbaros e ferozes? Um grande império com este lado tão fraco será na verdade a estátua de Nabuco donosor de pés de argila" ${ }^{\prime 3}$.

Os efeitos de uma insurreição deste tipo podiam ser observados na história de São Domingos, "primor da cultura colonial, jóia preciosa das Antilhas", onde ainda havia fumaça do "sacrifício de vítimas humanas e inocentes", que saíra do fogo ateado pelos "vingadores de Toussaint Louverture". Em suma, para Maciel da Costa, a ameaça à segurança do Estado era a principal questão posta pelo uso de escravos e "todas as outras considerações são subordinadas a esta e não podem se emparelhar com ela" ${ }^{\prime \prime}$.

$\mathrm{O}$ texto de José Bonifácio de Andrada e Silva expõe a adesão do autor aos mais bem acabados termos do antiescravismo do século XVIII europeu, o que pode ser verificado na sua condenação da escravidão "a favor da causa da justiça e ainda da sã política”. A “causa da justiça” indica pura e simplesmente que o autor havia abraçado o princípio de que escravidão era uma injustiça do ponto de vista do cristianismo e do direito natural, razão pela qual ele atacou o "bárbaro direito público das antigas nações”, responsável pela formulação dos fundamentos da legitimidade dessa instituição. "Com efeito”, escreveu Andrada e Silva, "os apologistas da escravidão escudam-se com os gregos e romanos, sem advertirem que entre os gregos e romanos não estavam ainda bem desenvolvidos e demonstrados os princípios eternos do direito natural e os divinos preceitos da religião" ${ }^{\prime 35}$.

Partindo desse princípio, a Representação... condena to das as justificativas da escravidão negra, a saber 1) os negros eram escravizados por um ato de caridade, pois, ao retirá-los da África, evitava-se que eles se tornassem "vítimas dos despóticos régulos"; 2) sua escravização era um serviço prestado à evangelização, ação esta "que todo cristão deve promover e espalhar"; 3) a vinda para a América os beneficiava na medida que saíam "de um clima e país ardente e horrível para outro doce, fértil e ameno" e, finalmente, o antigo arrazoado, baseado tanto no Direito das Gentes quanto no Direito Civil, segundo o qual o prisioneiro de guerra ou o criminoso deviam ser imediatamente mortos, sendo um favor a eles a conservação de suas vidas como escravos. 
Também está presente no texto de José Bonifácio um princípio do pensamento ilustrado que alicerçou essa crítica: trata-se, resumidamente, do alto valor concedido à liberdade pessoal. Para o autor, fundada na jus tiça, a sociedade civil tem por fim principal garantir a felicidade dos homens. Se, no entanto, a liberdade de um homem é roubada, assim como a "dos filhos deste homem e dos filhos destes filhos", não há justiça, inviabilizando a realização deste mesmo fim principal. E tem mais: a exigência de mudança da relação entre senhor e escravo não representa uma ameaça ao direito de propriedade. Segundo José Bonifácio, tal direito em nada será ofendido com esta mudança, pois o "homem, não podendo ser coisa, não pode ser objeto de propriedade. Se a lei deve defender a propriedade, muito mais deve defender a liberdade pessoal dos homens, que não pode ser propriedade de ninguém sem atacar os direitos da Providência que fez os homens livres e não escravos, sem atacar a ordem moral das sociedades, que é a execução estrita de todos os deveres prescritos pela natureza, pela religião e pela sã política". A não execução destas o brigações faz do governo a estátua de Nabucodonosor, "que uma pedra desprendida da montanha a derribou pelos pés. É um edifício fundado em areia solta que a mais pequena borrasca abate e desmorona" ${ }^{\prime 36}$.

Em síntese, ao condenar a escravidão em nome da "causa da justiça” José Bonifácio seguiu as linhas gerais dos argumentos humanitários do antiescravismo europeu dos fins do século XVIII.

Ao lado da "causa da justiça", a Representação ... mostra também o quanto a escravidão era um empecilho à "sã política". Isto porque, em primeiro, lugar, a escravidão prestava um serviço ao "antigo despotismo", interessado em que "fôssemos um povo mesclado e heterogêneo, sem nacionalidade e sem irmandade, para melhor nos escravizar". Agora, depois da Independência, como poderia haver uma "Constituição liberal e duradoura em um país continuamente habitado por uma multidão imensa de escravos brutais e inimigos?'; o fim da escravidão tornava-se, portanto, imperativo para que "venhamos a formar, em poucas gerações, uma nação homogênea", que não "se esfarele ao menor toque de qualquer nova convulsão política". Enfim, o risco representado pelos "inimigos domésticos" seria que eles "nada têm a perder, antes tudo que esperar de alguma revolução, como a de S. Domingos". Em segundo lugar, enumerou uma série de danos econômicos provocados pela escravidão: uma quantidade enorme de capitais era absorvida pelo tráfico negreiro, o escravo produzia pouco, a população não crescia, não havia progresso das artes, as máquinas eram desprezadas e o lucro da lavoura era muito baixo. Por fim, indi- 
cou os estragos que a escravidão acarretava à moral: "tiranizamos os escravos e os reduzimos a brutos animais, e eles nos inoculam to da a sua imoralidade e todos os seus vícios ${ }^{{ }^{\prime 37}}$.

Enfim, ao lado das manifestações de compaixão pelo escravo negro, há também no texto de José Bonifácio um conjunto de argumentos utilitários contra a escravidão, visando a implantação de uma "sã política" no Brasil.

Quanto ao artigo de José da Silva Lisboa, pode-se dizer que ele difere formalmente dos demais porque o autor deu-lhe a feição de ensaio. Desta maneira, trata tanto a escravidão quanto das reformas exigidas para que elas funcionem como fenômenos universais, e não como uma questão especificamente nacional.

No início do texto, encontra-se uma condenação genérica da instituição, feita em nome da moralidade e do cristianismo. Mas, argumentando que "seria crueza magoar uma chaga, que talvez se não possa curar", dada a antigüidade da instituição, presente na bíblica "era dos Chams", e os horrores que sempre causa, exortou os leitores a considerá-la "somente pelos resultados econômicos"38. Assim, foi do ponto de vista econômico que José da Silva Lisboa analisou a escravidão, mostrando, a partir das idéias de Adam Smith, a inferiondade do trabalho realizado pelo escravo, da qual deduziu a superioridade do trabalho livre.

Embora as considerações econômicas ocupem a maior parte do artigo, há também uma observação, feita de passagem, sobre os efeitos políticos da escravidão. Segundo Silva Lisboa, "onde se tem adotado a política da escravidão dos oriundos da África, não se vê, e é impossível formar-se um corpo de nação cordata", e mesmo entre os gregos e romanos os escravos provocaram "mil convulsões e misérias"39. Vale a pena destacar, por outro lado, que os resultados políticos destas "convulsões" estavam presentes na consciência do autor há um bocado de tempo, tanto que num texto de 1818, Silva Lisboa referiu-se ao "hórrido espetáculo da tremenda catástrofe da Rainha das Antilhas " ${ }^{40}$.

Em suma, vistos em conjunto, esses quatro textos mostram que os escritores brasileiros, observando a escravidão através do prisma das idéias antiescravistas da Ilustração, condenaram a instituição sob todos os ângulos. Em termos gerais, acompanharam a sensibilidade humanitária dos autores europeus, e consideraram a escravidão como um atentado ao direito natural e ao cristianismo; há, entretanto, dentro destes mesmos termos, duas posições antagônicas: Maciel da Costa, numa ponta, não acreditava que o tráfico fosse tão lesivo aos negros, ao passo que José Bonifácio, 
noutra, deu à liberdade pessoal valor superior ao que era dado à propriedade. Em termos particulares, no entanto, dedicaram maior atenção aos danos causados pela escravidão a dois elementos constitutivos da vida social: Estado e economia.

Quanto à economia, vê-se que seus autores estavam de fato convencidos de que a escravidão impedia a prosperidade; quanto ao Estado, consideravam-no ameaçado pelo que Gonçalves Chaves deno minou "expulções nigropolíticas”, na medida que a população escrava era sua inimiga declarada; a revolta de S. Domingos simplesmente evidenciava este fato, tendo sido mencionada em praticamente todos os textos. Não foi, portanto, sem motivo que Maciel da Costa e Andrada e Silva representaram alegoricamente o Estado brasileiro na sociedade escravista como a estátua de Nabucodonosor.

\section{AS MEDIDAS CONTRA A ESCRAVIDÃO}

Da mesma maneira que o antiescravismo foi o resultado de uma construção lenta e custosa, a confecção de medidas práticas para acabar com a escravidão não ocorreu do dia para a noite.

No quarto de século que se seguiu à publicação de $\mathrm{O}$ Espírito das Leis de Montesquieu, marcado pela lenta difusão do antiescravismo na França ${ }^{41}$, os autores que trataram do assunto nada disseram sobre a abolição. Havia apenas a sugestão de que era preciso reformar a instituição, abrandando-a de modo a torná-la mais humana, sendo desejável, no fim das contas, a sua desativação. De qualquer modo, não se encontra nenhum plano para a libertação dos escravos nessa época.

A partir da década de 1780, no entanto, sob o impulso do amadurecimento da crítica filosófica à escravidão, da demonstração dos fisiocratas de que era viável a substituição dos escravos por trabalhadores livres, das notícias que chegavam na Europa sobre a libertação dos escravos pelos quacres e da formação de sociedades antiescravistas nos Estados Unidos, a partir dos anos de 1780, repito, alguns escritores começaram a considerar a abolição como uma questão prática, elaborando planos para executá-la. Um exemplo desta nova posição encontra-se nas Reflexões sobre a Escravidão dos Negros de Condorcert, publicadas em 1781; mas, pode-se ter uma idéia da lentidão e dos cuidados necessários para os avanços neste terreno se for considerada a posição extremamente cautelosa de Condorcet ao sugerir a abolição gradual.

Somente na década de 1780, foram fundadas sociedades abolicionistas na Europa, tendo sido a primeira delas criada na Inglaterra, em 
1783, para lutar pelo fim do tráfico negreiro. Mas, suas atividades só se iniciaram efetivamente em 1787, graças à ação política de Thomas Clarkson, Glanville Sharp e James Phillips, quando passou a se chamar "Sociedade pela abolição do tráfico e da escravidão dos negros". Na França, a primeira data de 1788: trata-se da "Sociedade dos Amigos dos Negros", que tinha à testa figuras como Brissot, La Fayette, Mirabeau, Clavière, Condorcet, Sieyès, Grégoire, Lavoiser, Pétion, etc.

Na virada do século XVIII para o século XIX, depois que os franceses aboliram a escravidão em 1794, uma informação dada por G régoire nas suas Memónias permite saber em que ponto estava o antiescravismo:

quanto aos escravos, não é preciso precipitar sua emancipação, mas conduzi-los gradualmente às vantagens do estado social: assim pensavam Brissot, Wadstrom, Pétion, Lanthemas, etc., e toda a Sociedade dos Amigos dos Negros, da qual eu era membro; assim pensavam Wilbeforce, Barlow, Fox, Clarkson, Thorton, Granville, Sharp, com os quais estabeleci ligações; assim pensavam as sociedades estabelecidas nos Estados Unidos para melhorar a sorte dos negros e que me enviavam anualmente os processos verbais da Convenção Central na Filadélfia. Concebia-se, desde então, que a emancipação súbita, pronunciada no decreto do 16 pluvioso do ano II, animada por Levasseur (de la Sarthe), nos pareceu uma medida desastrosa: ele era para a política o que um vulcão é para a física $(. . .)^{42}$.

No primeiro quarto do século XIX, este quadro foi mantido, apesar de alguns abolicionistas terem levado o debate sobre fim da escravidão nas colônias inglesas para dentro do Parlamento. Importa é que as medidas práticas propostas pelo antiescravismo brasileiro dos princípios do século XIX se mantiveram dentro destes mesmos limites.

Gonçalves Chaves sugeriu que, dada a instalação de D. João VI no Rio de Janeiro, o fim do tráfico negreiro era necessário à constituição do Estado, "pela via mais próxima, e compatível com as circunstâncias, e ainda que este passo é indispensável, tem espinhos maus de pisar". Para tanto, seria dado aos traficantes um prazo de 18 meses "para disporem de seus fundos", após o que esse comércio seria proibido, devendo, em seguida, ser sancionada "alguma lei em favor da liberdade dos oriundos dos cativos existentes". Tal medida, afirmava o mesmo autor, não significaria "nem um ceitil" de ofensa ao direito de propriedade pública ou particular, pois "nada é mais fácil ao negociante do que mudar de mercadorias, ao viajante de viagem, e ao lavrador de plantação". O problema maior do tráfico, segundo Gonçalves Chaves, era o fato de que ele deixava o Brasil 
com um "excessivo número de escravos", um obstáculo intransponível para que fossem tratados de maneira adequada. Com a interrupção do tráfico, portanto, os escravos passariam a receber melhor tratamento e leis promoveriam a emancipação gradual "por via de associações filantrópicas, quando já estejamos certos de que nossa força física excede a da raça negra", pela libertação dos escravos da segunda ou terceira geração "em que consecutivamente tenha entrado mistura de cor branca" ou pela liberdade de todo filho de cativos ao vinte e cinco anos ${ }^{43}$.

João Severiano Maciel da Costa, diferentemente de Gonçalves Chaves, não estabeleceu "quando e como se deve abolir", por acreditar ser este "um negócio essencialmente ligado aos planos políticos ministeriais que não ousamos perscrutar"44. Tal medida deveria ser planejada pelo soberano, que "conhece melhor que ninguém os interesses de sua poderosa monarquia, e no seu paternal desvelo devemos depositar to dos a mais limitada confiança". Além do mais, tratava-se de uma "empresa dificílima", pois dará "nova direção à indústria e trabalhos de um povo inteiro". De qualquer maneira, "todas as medidas rápidas e diretas são desaconselhadas pela política", razão pela qual o Estado deveria interromper a introdução de escravos africanos e, ao mesmo tempo, encontrar "meios de remediar a falta que este sucesso deve ocasionar".

Sugeriu, enfim, medidas para melhorar a condição do escravo, a saber, 1) poupar os escravos, tratando-os como "homens e filhos do Criador", e promover os casamentos entre eles para que surja uma população crioula, que formará uma "excelente raça de trabalhadores"; 2) inspirar o amor do trabalho aos livres da classe do povo de todas as cores, e, por meio de uma "polícia vigilante e severa", não consentir "ociosidade nesta classe de gente, trazendo-a registrada e até inventariada"; 3) empregar os indígenas e 4) atrair europeus.

Um dos objetos da Representação... de Jo sé Bonifácio de Andrada e Silva era propor uma "uma nova lei sobre o comércio da escravatura e tratamento dos miseráveis cativos"; por isto, o seu texto pretende mostrar "a necessidade de abolir o tráfico da escravatura, de melhorar a sorte dos atuais cativos e de promover a sua progressiva emancipação". Aliás, para o autor, a melhoria da condição dos escravos existentes, por si mesma, seria "um passo dado para a sua futura emancipação" ${ }^{45}$, que não deveria ser feita "de repente", porque causaria "grandes males".

Como considerou que o escravo deveria ser digno da liberdade que lhe será concedida, José Bonifácio exortava de uma só vez os deputados a abrandar o seu "sofrimento", favorecer e aumentar "todos os seus go- 
zos civis domésticos e civis" e instrui-los "no fundo da verdadeira religião de Jesus Cristo e não em momices e superstições". Deste modo, eles começariam a ter acesso à dose de civilização que podem alcançar "no seu desgraçado estado, despojando-os o menos que pudermos da dignidade de homens e cidadãos". Esta seria a condição para que viessem a prestar serviços "com fidelidade e amor; de inimigos se tornarão nossos amigos e clientes", tornando possível ao homem livre viver "sem medo e contente no meio de seus escravos como no meio da sua própria família"46.

Para a concretização desse plano, o projeto do autor previa impostos dobrados sobre os escravos importados, até a aprovação de uma lei que extinguiria o tráfico negreiro em cinco ou seis anos. Finalmente, projetou um pequeno código, com cerca de trinta artigos, para melhorar as condições dos escravos e assegurar-lhes o que chamou de "proteção civil". A sugestão de Silva Lisboa tem o mesmo caráter genérico que enforma seu texto: competiria ao soberano dar "eficaz proteção ao escravo contra a tirania dos seus senhores". Isto porque, "onde se tolera, ou se considera indispensável ter escravos, é preciso, que o jugo seja doce, para não ser inútil", muito embora o "simples cálculo de interesse" mostre "o erro econômico de procurar enriquecer alguém com escravaturas" ${ }^{47}$. Deste modo, a mitigação da escravidão foi a única medida prática por ele preconizada para corrigir os defeitos da instituição.

Embora apresentem diferenças nos detalhes dos planos, todos esses textos seguem uma mesma linha ao propor etapas para a emancipação dos escravos. A primeira medida prática sugerida pelos autores, exceto porJosé da Silva Lisboa, foi o fim do tráfico negreiro. Consideravam que, desmantelado este comércio, a dificuldade de reposição o brigaria os proprietários a dar um melhor tratamento aos escravos; ao mesmo tempo, o Estado entraria em cena tomando medidas não só para dar-lhes "proteção civil", como também para implementar uma emancipação gradual, cujo término aliás nenhum autor ousou prever, substituindo os escravos negros por índios ou imigrantes europeus.

De uma só vez, todos esses autores deixaram o fim da emancipação gradual para as calendas e prescreveram uma providência para realizar uma reforma imediata: a mitigação da escravidão, por acreditar que somente por meio dela haveria a redução dos perigos e a otimização da produção. Pode-se dizer assim que o substrato da doutrina antiescravista formulada no Brasil do início do século XIX reside no projeto de mitigação da escravidão, em vista da sua constância nos textos desses escritores aqui examinados. 
Em princípio, para efeitos de balanço final, é preciso reconhecer que não há ineditismo algum nas idéias desse antiescravismo brasileiro. De fato, a adesão dos seus autores à crítica ilustrada da escravidão, formulada durante a segunda metade do século XVIII, foi de tal ordem que eles apenas repetiram idéias e vocabulário dos franceses.

É isso que se vê no tratamento dado a um assunto que constituiu a espinha dorsal do antiescravismo: as medidas para abolir a escravidão. Como se sabe, para os autores brasileiros a abolição ocorreria no fim de um percurso marcado pela sucessão das seguintes etapas: fim do tráfico negreiro, abrandamento da escravidão sob o controle do Estado e início da abolição gradual.

Em 1789, Frossard havia sugerido a mesma seqüência, com a vantagem de enunciar claramente que o objetivo do seu projeto visava garantir "os benefícios recíprocos da nação, dos senhores e dos escravos" ${ }^{48}$, ou seja, a compaixão pela condição dos escravos e a defesa interesses da nação e dos senhores estavam num mesmo plano, e todos mereciam a mesma consideração para fins de encaminhamento da abolição.

Partindo desse ponto, Frossard solicitou "a benevolência do governo e da justiça dos colonos americanos não para a libertação imediata e geral dos negros que cultivam nossas Ilhas, mas para abolir o tráfico, que sacrifica todo ano novas vítimas para atender a nossa cupidez". Realizada esta primeira etapa, a libertação dos escravos, "um projeto sublime na teoria", deveria ser executada gradualmente, "a fim de que nem as colônias, nem os colonos sejam prejudicados" ${ }^{\prime 9}$.

Quanto à mitigação da escravidão, transformada pelos brasileiros em doutrina, Raynal, num capítulo intitulado "Como será possível tornar o estado dos escravos mais suportável” do Tomo VI da sua História Filo sófica... ., já havia expressado a seguinte opinião "a história de todos os povos demonstra que, para tornar a escravidão útil, é preciso ao menos abrandá-la". Tal "moderação política", dizia, será atingida pela redução do tempo de trabalho e suavização das penas, disposições estas que devolveriam ao escravo "uma parte de seus direitos, para então retirar mais seguramente o tributo dos deveres que lhe são impostos". Além disso, algumas "diversões econômicas" deveriam ser permitidas, como festas, jogos e prêmios, impedindo "a estupidez tão comum entre os escravos, alegrando seus trabalhos e os preservando dessa tristeza devorante que os consome e abrevia seus dias" ${ }^{\prime 50}$. Depois de expor essas sugestões, Raynal 
apresentou também, na edição de 1780 da História Filosófica... , um plano para a abolição gradual.

Algo semelhante se encontra na Reflexão... de Condorcet, que apregoou meios para "amenizar desde já o estado dos negros e destruir a escravidão numa época fixa e pouco distante”; esta última medida deveria ser gradual: ela se iniciaria com a extinção do tráfico, sendo seguida pela libertação dos filhos de escravos, etc. Se para José Bonifácio a mitigação seria o primeiro passo para a emancipação, segundo Condorcet as leis que ele mesmo propunha "parecem as mais seguras para destruir gradualmente a escravidão, e para mitigá-la enquanto subsistir"; tais leis, afirmou, "não tornarão a escravidão legítima, mas sim menos bárbara e compatível senão com a justiça, ao menos com a humanidade ${ }^{{ }_{51}}$. Frossard também proclamou a necessidade da mitigação; ao tratar da pressão dos quacres sobre o Parlamento inglês para proibir o tráfico, afirmou que, concretizada esta medida, todos os donos de escravos serão forçados a "se não libertá-los, ao menos tratá-los com benevolência"52. E o texto de Grégoire, acima citado, mostra que havia um consenso dos abolicionistas europeus dos fins do século XVIII sobre a necessidade de mitigar a escravidão.

A reprodução das idéias dos ilustrados franceses pelos brasileiros ocorreu não somente em relação às medidas para acabar com a escravidão, mas está igualmente presente nas críticas feitas à instituição. Todo o arrazoado humanitário contra a escravidão que apresentaram foi originalmente formulado a partir das idéias dos quacres e de Montesquieu, tendo sido ampliadas pelos críticos da instituição ao longo da segunda metade do século XVIII.

A questão da ameaça que a escravidão representa à segurança e à prosperidade do Estado, tratada por Soares Franco e destacada nos escritos de Gonçalves Chaves e Maciel da Costa, tem uma longa trajetória na história do antiescravismo francês. De Montesquieu até Frossard, encontram-se idéias sobre os perigos da escravidão e a sobre a superioridade do trabalho do homem livre; Frossard, por exemplo, afirmou que "sem a liberdade pessoal, uma nação não terá nem segurança nem esplendor; a opressão conduz à revolta...", ou então que a escravidão é lesiva tanto à "prosperidade do Estado quanto aos interesses dos particulares" ${ }_{53}$.

Comparando-se, por outro lado, o vocabulário de José Bonifácio, mais especificamente o destaque que deu à "causa da justiça e sã política", com o de Frossard, vê-se que a expressão "causa", no mesmo senti- 
do que lhe deu o brasileiro, aparece no título do livro deste último, dentro do qual se encontra também a expressão "sã política"54.

A referência constante à revolta de $\mathrm{S}$. Domingos nos textos apresentados, retratando-a como o ponto mais alto das "expulções nigropolíticas", chamou a atenção de historiadores brasileiros e os levou a atribuir aos seus autores o papel de porta-vozes de uma elite que temia a "haitinização" do Brasil. A questão, entretanto, tem uma outra dimensão, tão importante quanto esta. Quando Montesquieu advertiu sobre os "perigos" da escravidão, decerto pensava que esta era uma conseqüência da situação do escravo à margem dos direitos civis e políticos. Partindo deste argumento, o antiescravismo da segunda metade do século XVIII explorou a idéia de que, por estarem relegados a essa condição, só restava aos escravos uma única forma de manifestação: a revolta. Isto não quer dizer, no entanto, que os escritores da Ilustração estivessem predicando a sublevação dos escravos; na verdade, a idéia da revolta foi usada para fins retóricos, a fim de persuadir sobre a necessidade de reformar a escravidão; em síntese, ao recorrer a esse assunto, os escritores deixavam subentendido que a implementação de reformas era o único meio de evitar a revolta.

A propósito, vale a pena reproduzir um trecho escrito por Raynal, que, por estar repleto de fortes imagens sobre a rebelião dos escravos, permite compreender o que se quer dizer com uso da revolta para efeitos retóricos. Uma década antes da revolta de S. Domingos, Raynal escreveu que

só falta aos negros um chefe bastante corajoso para conduzi-los à vingança e à carnificina. Onde está este homem que a natureza deve aos seus filhos vexados, oprimidos, atormentados? Onde está?Ele aparecerá, não duvidemos, e se apresentará carregando o estandarte sagrado da liberdade. Este sinal venerável reunirá em torno dele seus companheiros de infortúnio. Mais impetuosos que as torrentes, deixarão em todos os lugares os traços indeléveis dos seus justos ressentimentos. Espanhóis, portugueses, ingleses, franceses, holandeses, todos os seus tiranos se tornarão presas do ferro e das chamas. (...) O velho mundo aplaudirá o novo. Em todos os lugares será abençoado o nome do herói que restabelecerá os direitos da espécie humana, e em todos os lugares se levantarão troféus à sua glónia. Assim, desaparecerá o code noir; e o code blanc será terível se o vencedor consultar apenas o direito de represália”55.

Esta não foi nem uma expressão dos anseios do autor, nem tampou- 
co uma profecia sobre Toussaint Loverture, mas sim o esforço de Raynal para persuadir por intimidação seus contemporâneos so bre a necessidade de reformar a escravidão. Em outros termos e com outras tintas, mas com a mesma intenção, os escritores brasileiros usaram a imagem de S. Domingos da mesma maneira. Assim, a revolta de S. Domingos, em 1791, tornou-se o mais bem-acabado exemplo dos riscos causados pela escravidão; como tal, foi apropriado pelo pensamento antiescravista para cobrar a urgência das reformas, prestando serviços aos discursos que reclamavam mudanças na escravidão.

Mas, embora tenha reproduzido as principais linhas da crítica francesa à escravidão, o antiescravismo brasileiro tem uma especificidade que pode ser observada em dois dos seus aspectos constitutivos. Um deles, apreendido ao primeiro contato, é "externo", e manifesta-se no gênero literário que veicula os textos; o outro pode ser denominado "interno" por oposição ao primeiro, e encontra-se no caráter dos textos.

O aspecto externo é visível por ter sido o antiescravismo apresentado num gênero literário, do qual se exclui somente o ensaio de José da Silva Lisboa. Com efeito, Gonçalves Chaves e Maciel escreveram Memó rias , isto é, dissertaçõ es sobre os males da escravidão, e as remeteram, respectivamente, para as apreciações do Trono do recém fundado Reino Unido e das Cortes Constituintes; José Bonifácio, por sua vez, escreveu uma Representação que deveria ser discutida pelos deputados da Assembléia Constituinte de 1823.

Desse modo, os textos tinham uma destinação precisa: formalmente solicitavam providências sobre a escravidão a instituições governamentais. Mas, poder-se-ia perguntar, essa especificidade não perderia o sentido mediante a simples lembrança de que, na França, em 1792, Frossard também entrego u à Convenção um resumo das suas opiniões contra o tráfico negreiro ${ }^{56} \mathrm{e}$ diversos abolicionistas ingleses enviaram seus escritos sobre a escravidão ao Parlamento? Certamente que não, pois há de se levar em conta a radical diferença existente entre todos esses homens e os brasileiros. A solicitação de providências do governo contra a escravidão pelos europeus era apenas um dos aspectos da militância antiescravista desses homens; os brasileiros, ao contrário, nunca militaram contra a escravidão e escrever os textos aqui apresentados foi a única atividade antiescravista que tiveram durante suas vidas. Além do mais, todos participavam do governo, o que, passado para outros termos, significa que o antiescravismo no Brasil dos princípios do século XIX foi uma manifestação de 
uns poucos membros do governo que se limitaram a submeter projetos de reforma da escravidão à apreciação de instituições do governo.

O corre que, vivendo numa sociedade escravista, esses homens só puderam ocupar a posições políticas que de fato ocuparam por pertencerem à elite dos homens livres. Baseado no lugar social e político que os seus autores ocuparam, o antiescravismo brasileiro dos princípios do século XIX exibiu uma visão do presente e uma idealização do futuro da sociedade; nela apontavam os males da escravidão, que, na idealização, seriam extirpados com o fim do tráfico e com as reformas.

A comprovação de que o antiescravismo em tela traduzia uma visão da sociedade e uma idealização do futuro de uma elite está no caráter dos textos, ou seja, no aspecto "interno" da sua especificidade, e se revela, primeiro, na ênfase emprestada pelos autores a determinados assuntos e, segundo, na adoção de determinados princípios para dissertar sobre eles.

Quanto à ênfase, verifica-se que os autores, salvo José Bonifácio que balanceou a distribuição dos assuntos, deram destaque aos efeitos nocivos causados pela escravidão ao Estado e à economia, relegando a segundo plano a crítica humanitária da mesma instituição. Assim, uma comparação entre os textos antiescravistas dos europeus com os dos brasileiros permite verificar que esses últimos inverteram a ênfase dada pelos primeiros aos assuntos: a questão humanitánia, prioritária para os europeus, tornou-se secundária para os brasileiros, do mesmo modo que a questão da ameaça da escravidão à segurança do Estado e à prosperidade, que era secundária, tornou-se prioritária. Aliás, são escassos os comentários dos brasileiros sobre as condições de vida dos escravos, indicativo de que, a seus olhos, não havia nada de extrao rdinário a respeito de uma matéria que lhes parecia "natural". Tanto é assim que Maciel da Costa chegou até mesmo a afirmar que, através de "vidros de engrossar", os "amigos da humanidade" cometem exageros ao retratar a escravidão, e Silva Lisboa recusou-se a censurá-la, sob o argumento de que "seria crueza magoar uma chaga, que talvez não se possa curar".

Dentro do mesmo movimento de inversão dos valores, ao contrário dos franceses do século XVIII, os autores calaram-se sobre os destinos do escravos depois da abolição. Raynal, havia sugerido que, com o fim da escravidão, os novos cidadãos deviam receber "uma cabana com um terreno suficiente para ter um pequeno jardim", cabendo ao governo cobrir as despesas necessárias à sua conservação. Além disso, "nenhum regulamento privará esses homens, que se tornaram livres, da faculdade de es-

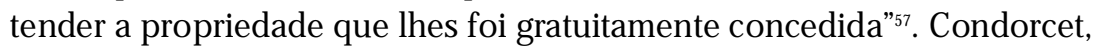


por sua vez, propôs que, nas mesmas circunstâncias, os ex-escravos com mais de cinqüenta anos teriam duas alternativas: permanecer com o seu senhor ou entrar num estabelecimento público; caso escolhessem esta última, seriam mantidos por uma pensão paga pelo antigo senhor, "que lucrou com seu trabalho durante toda a vida". Tal obrigação dos senhores não seria um injustiça, prosseguia Condorcet, pois "depois de ter exercido durante cinqüenta anos uma injustiça horrível sobre esses infelizes; depois de ter se aproveitado mais de trinta anos do seu trabalho, ele deve ao escravo, em virtude do direito natural, e independentemente de qualquer lei, não somente a subsistência, mas também uma indenização. De qualquer modo, respeitamos demasiadamente a avareza dos senhores, para nada exigir além da subsistência" ${ }^{58}$.

Em contraste com os propósitos de Raynal e Condorcet, o ponto mais longínquo que os autores brasileiros conseguiram vislumbrar sobre o futuro dos escravos encontra-se no propósito de José Bonifácio de transformá-los em arrendatários: "os forros aumentados, para ganharem a vida, aforarão pequenas porções de terras descobertas ou taperas que hoje nada valem"; por conseguinte, todo o sistema seria beneficiado, pois "os bens rurais serão estáveis e a renda da terra não se confundirá com a do trabalho e indústria individual" ${ }^{\prime 2}$. O mutismo dos demais autores brasileiros sobre o mesmo assunto permite deduzir que eles supunham que os sucedâneos dos escravos seriam trabalhadores devotados aos patrões e ao Estado, bem como homens empenhados em promover a prosperidade nacional.

Em suma, para esse antiescravismo o escravo era visto como um trabalhador ineficiente e perigoso à ordem constituída; o seu sucedâneo, o homem livre, era idealizado como um trabalhador diligente e cordato. Sendo assim, com o fim do tráfico e as reformas da escravidão estaria desencadeado um processo que garantiria o máximo de benefícios para a elite. Vê-se, portanto, o porquê da crítica de Gonçalves Chaves e de Maciel da Costa a Raynal: o padre francês representava uma ameaça à conservação da ordem vigente ao imaginar que os escravos se transformariam em proprietários. Inversamente, vê-se também o porquê da adoção dos princípios antiescravistas de Montesquieu e Adam Smith por todos os autores.

Das idéias de Montesquieu os brasileiros puderam extrair o fundamento da doutrina da mitigação. Embora o autor do Espírito das Leis tivesse criticado a escravidão, nunca advogou a sua extinção imediata. Russel P. Jameson, autor do mais completo estudo sobre o antiescravismo de 
Montesquieu, localizou "a última palavra de Montesquieu sobre a escra-

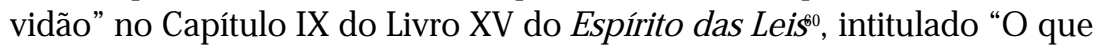
as leis devem fazer com relação à escravidão"; este capítulo é formado por uma única frase: "porém, qualquer que seja a natureza da escravidão, cumpre que as leis civis procurem dela extirpar, de um lado, os abusos e, de outro, os perigos". Assim, Montesquieu acreditava que a escravidão, empregada em certas circunstâncias, apesar da injustiça causada pelos abusos que lhe são inerentes, e dos perigos que representa, teria o seu bom funcionamento garantido se fosse regulada por leis adequadas.

Por outro lado, ao aderir à crítica dos economistas, os brasileiros podiam, quando muito, propagar a necessidade de uma tomada de consciência da ineficácia econômica da escravidão e adotar o princípio novo, preconizado pela Economia Política, de que o emprego do trabalho livre era viável e vantajoso. De qualquer maneira, seja seguindo a crítica de Montesquieu à escravidão, seja seguindo a da Economia Política, seja aderindo a ambas, os escritores brasileiros entregavam ao Estado a incumbência de reformar a escravidão, o que vale dizer que se desobrigavam de qualquer ação para alterar o estado de coisas, pouco importando-se, ao mesmo tempo, com a condição da maioria da população, constituída por homens negros escravizados.

No fim das contas, Montesquieu e Adam Smith vinham a calhar, pois tinham muito a dizer sobre segurança e prosperidade, na medida em que o primeiro, no seu empenho para construir um conhecimento racional do governo, havia alertado sobre os perigos da escravidão e o segundo, que fundara uma Economia Política como "ciência do estadista ou do legislador", cujo propósito era o de "enriquecer tanto os indivíduos como o soberano" ${ }^{\prime 1}$, havia mostrado que a escravidão era nociva à constituição da riqueza nacional. Mas nenhum dos dois ilustrados havia manifestado qualquer preocupação com os destinos dos negros escravizados depois da emancipação. Sendo assim, ao considerarem a questão da escravidão pelo prisma dos princípios de Montesquieu e Adam Smith, os autores brasileiros tinham em vista a implantação de um sistema que proporcionaria segurança e prosperidade; para eles, tal como os princípios que escoravam suas idéias, não havia lugar para preocupações com a população negra.

Enfim, a falta de originalidade das primeiras idéias antiescravistas publicadas no Brasil do primeiro quarto do século XIX não tem grande relevância por si mesma, haja vista que a escravidão negra também não era um fato estritamente nacional. Com efeito, se, a partir dos fins do século XVIII, passou a existir uma "Internacional" antiescravista, formada 
por asso ciaçõ es americanas, inglesa e francesa que lutavam pelo fim do tráfico ou da escravidão e comungavam as mesmas idéias e projetos, não há motivo para caracterizar como excepcional quer seja a inexistência de um antiescravismo genuinamente brasileiro, quer seja a adoção pelos brasileiros de idéias antiescravistas da Ilustração.

O que há de genuíno é o caráter assumido pelo antiescravismo no Brasil. Aqui ele foi assimilado por alguns letrados ligados ao governo, os quais se limitaram a pleitear reformas da escravidão a serem efetuadas pelo Estado em benefício da sua própria conservação e da prosperidade nacional, visando garantir a preservação do status quo da elite; tanto foi assim que esses autores criticaram a escravidão negra sem nada discutir sobre os destinos dos homens negros escravizados.

\section{NOTAS}

${ }^{*}$ Este texto foi apresentado, em junho de 1999, no $10^{\circ}$ Congresso Internacional da Ilustração em Dublin, Irlanda.

${ }^{1}$ EHRARD, Jean. "L'esclavage devant la conscience morale des lumières françaises: indifférence, géne, révolte". In Les Abolitions de l'Esclavage. De Sonthonax à V. Schoelcher. Vincennes, Presses Universitaires de Vincennes/UNESCO, 1995, p. 137.

${ }^{2} \mathrm{SMITH}, \mathrm{Adam}$. An Inquiry into the Nature and Causes of the Wealth of Nations (1776). CAMPBELL, R.H. and SKINNER, A.S. (ed.), Indianapolis, Liberty Fund, 2 v., 1981, I, p.387.

${ }^{3}$ RAYNAL, Guillaume-Thomas. Histoire Philosophique et Politique des Établissemens et du Commerce des Européens das les Deux Indes Genève, Pellet, 1780, 10 t., t. I, p.27.

${ }^{4}$ STORCH, H. Cours d'Économie Politique ou Exposition des Principes que determinent la Prospérité des Nations Paris, Aillaud, 1823, 4 vol., 3ํㅡol., p.141.

${ }^{5} \mathrm{O}$ conceito de sociedade escravista foi formulado por Finley. Refere-se a um tipo de sociedade para a qual a escravidão é uma "instituição essencial", tanto para a produção quanto para o estilo de vida nelas existente. Segundo Finley, na história só houve cinco sociedades deste gênero: a grega a romana clássicas, e, na era moderna, a brasileira, a caribenha e a sulista dos EUA. FINLEY, M.I. “A Peculiar Institution?”. In The Times Literary Supplement, 2/7/1976, p.819.

${ }^{6}$ Sobre a penetração das idéias ilustradas no mundo português ver o capítulo "Os 'Cafres da Europa', o Renascimento e o Iluminismo" de O Império Colonial Português de C. R. Boxer (trad. port., Lisboa, Edições 70, 1977).

${ }^{7}$ Refiro-me aos artigos de DIAS, Maria Odila Silva. "Aspectos da Ilustração no Brasil”.In Re vista do Instituto Histórico e Geográfico Brasileiro. ํㅡ278, 1968, pp.105-170 e MAXWEL, R. Kenneth. "The Generation of 1790s and the Idea of Luso Brazilian Roots of Modern Brazil". In AUDEN, Dauril (dir.). Colonial Roots of Modern Brazil. Berkeley, 1973.

${ }^{8}$ A propósito de idéais sobre a escravidão no Brasil dos princípios do século XIX, ver "Por detrás dos panos: atitudes antiescravistas e a Independência do Brasil"de Lucia Maria Bas- 
tos P. Neves in Maria Beatriz Nizza da Silva (org.). Brasil: colonização e escravidão. Rio de Janeiro, Nova Fronteira, 2000.

${ }^{9}$ Cabe esclarecer que de fato estes textos foram escritos entre os anos de 1817 e fins da década de 1820; as datas que se seguem aos títulos são as da primeira edição de cada um deles. Todos eles tiveram cuidadosas reedições no no século XX, que serão aqui utilizadas.

${ }^{10}$ Assim, por exemplo, Fernando Henrique Cardoso utilizou as observações de Gonçalves Chaves no Capitalismo e escravIdão no Brasil Meridional (São Paulo, Difel, 1962); José Murilo de Carvalho asso ciou a discussão sobre a escravidão negra feita por Andrada e Silva com as questões relativas à organização do estado nacional brasileiro no artigo "Escravidão e Razão Nacional" (Dados - Revista de Ciências Sociais, 31, 1988, pp. 287-308; Leslie Bethell em A Abolição do Tráfico de Escravos no Brasil (trad. port., Rio de Janeiro, Expressão e Cultura/EDUSP, 1976) e Robert Conrad em Os Últimos Anos da escravatura no Brasil (trad. port. Rio de Janeiro, MEC/Civilização Brasileira, 1975) usaram os textos de Severiano da Costa e Andrada e Silva.

${ }^{11}$ A lista destas publicações pode ser encontrada num apêndice (pp.197-199) em SEEBER, Edward Derbyshire. Anti-Slavery opinion in France during the second half of the Eigh teenth Century. (Baltimore, The John Hopkins Press, 1937).

${ }^{12}$ Sobre essa questão, ver "Pálidas e oblíquas luzes: J.J. da C. Azeredo Coutinho e a "Análise sobre a justiça do comércio do resgate dos escravos" de Guilherme Pereira das Neves in Maria Beatriz Nizza da Silva (org.), op.cit.

${ }^{13}$ Embora suas Memórias econômico-políticas tenham sido publicadas em 1822, a terceira delas, intitulada "Sobre a Escravatura", resulta de um "Discurso"que, segundo o autor, foi "escripto em 1817".

${ }^{14}$ CHAVES, Antonio José Gonçalves. Memórias economo-políticas. Ed. e introd. de J. B. Hafkemeyer S. J., Revista do Instituto Histórico e Geográphico do Rio Grande do Sul, II e III trimestre, 1922, p.48.

${ }^{15}$ Idem, p.38.

${ }^{16}$ Vê-se que há uma incompatibilidade entre as datas de redação dos textos de Gonçalves Chaves e Soares Franco. Chaves afirmou que escrevera seu texto sobre a escravidão em 1817, enquanto Soares, na "Introdução" do seu Ensaio , disse que havia começado a "tratar de algumas Memórias em 1806"; estas, entretanto, só foram editadas em 1820, quando houve "favoráveis ocasiões para a sua correção, e publicação" (p. 03). J. B. Hafkemeyer, responsável pela reedição das Memórias economo-políticas em 1922, aceitou um comentário de Varnhagen, segundo o qual o seu autor instalou-se no Rio Grande do Sul em 1806, fato este aliás confirmado pelo próprio Gonçalves Chaves no título do livro, cuja autoria é atribuída a "um português, residente no Brasil há 16 anos (...)". Enfim, em vista desta contradição das datas, resta formular uma hipótese: é provável que Gonçalves Chaves tenha feito uma primeira redação do texto em 1817, e impôs-lhe mudanças depois de ter lido o livro de Soares Franco em 1820.

${ }^{17}$ MACIEL da COSTA, João Severiano. Memória sobre a necessidade de abolir a introdução de escravos africanos no Brasil, sobre o modo e condições com que esta abolição se deve fazer e sobre os meios de remediar a falta de braços que ela pode ocasionar (1820). In Me mórias da escravidão. Introdução de Graça Salgado, Rio de Janeiro, Arquivo Nacional, 1988, pp. 13, 49 e 54 . 
${ }^{18}$ ANDRADA e SILVA, José Bonifácio. "Representação à Assembléia Geral Constituinte e Legislativa do Império do Brasil sobre a escravatura (1825)". In Memórias da escravidão , op. cit., p.67.

${ }^{19}$ WELEURSSE, Georges. Le Mouvemente Physiocratique en France (1756-1770). $2^{\underline{a}}$ ed., Paris/Haia, Mouton, 2 v., 1968, I, p.158

${ }^{20}$ SEEBER, Edward Derbyshire. Anti-Slavery opinion in France during the second half of the Eighteenth Century. Baltimore, The John Hopkins Press, 1937, p.110.

${ }^{21}$ Este artigo foi publicado pela primeira vez no tomo II da revista Guanabara de 1851 e compendia as idéias sobre a escravidão de José da Silva Lisboa, Visconde de Cairu, que havia tratado do mesmo assunto numa série de outros livros. Mas, trata-se de um texto póstumo - Cairu faleceu em 1835 -, e não há dados sobre a sua história. Ver ROCHA, Antonio Penalves "Um documento antiescravista do primeiro terço do século XIX”. In Revista de His tória, ํㅡ137, 1997, pp. 123-137.

${ }^{22}$ DAVIS, David Brion. The Problem of Slavery in the Age of Revolution 1770-1823. Ithaca, Cornell University Press, 1975, p.45.

${ }^{23}$ Ver, a propósito da fontes de Jaucourt, o artigo de Davis Brion David "New sidelights on early antislavery radicalism". In William and Mary Quarterly , 3d. ser., XXVIII (585-594), oct. 1971.

${ }^{24}$ Um balanço das análises sobre as relações entre antiescravismo e o mundo europeu do século XVIII acha-se em BENDER, Thomas (ed.) The Antislavery Debate. Capitalism and abolicionism as a problem in historical interpr etations. Berkeley, University of California Press, 1992. Ver também a resenha deste livro feita por Seymour Drescher, publicada pela History and Theory. vol. 32, no 03, 1993, pp.311-329.

${ }^{25}$ CHAVES, op. cit., pp. 32 e 36.

${ }^{26}$ Idem, p.37.

${ }^{27}$ Idem, pp. 39 e 40.

${ }^{28}$ Idem, pp. 41 e 44.

${ }^{29}$ FRANCO , Francisco Soares. Ensaio sobre os Melhoramentos de Portugal e do Brasil. Lisboa, Imprensa Nacional, 1821, p. 05.

${ }^{30}$ MACIEL da COSTA, op. cit., p.13.

${ }^{31}$ Idem, pp. 16 e 17.

${ }^{32}$ Idem, pp. 13, 21 e 47.

${ }^{33}$ Idem, p. 22..

${ }^{34}$ Idem.

${ }^{35}$ ANDRADA E SILVA. op. cit., pp. 63 e 65.

${ }^{36}$ Idem, pp.68 e 69.

${ }^{37}$ Idem, pp. 63-65 e 75.

${ }^{38}$ LISBOA, op. cit., pp. 131 e 132.

${ }^{39}$ Idem, p.135. 
${ }^{40}$ LISBOA, José da Silva, Memória dos Benefícios Políticos do Governo de El-Rey Nosso Senhor D. João VI. Rio de Janeiro, Impressão Régia, 1818, p.160

${ }^{41}$ Revelando a inexpressiva quantidade de manifestações contra a escravidão em 1771, Du Pont de Nemours, ao resenhar as Cartas Africanas... de Butini no tomo VIII do periódico oficial dos fisiocratas -Efemérides do Cidadão ou Biblioteca Racional das Ciências Morais e Políticas -, apresentou uma lista dos escritores e filósofos que até então haviam se manifestado a "favor da liberdade e da justiça", em benefício do "progresso das luzes". Encabeçando a lista, estava Montesquieu, com o "primeiro ataque que ridicularizou os pretensos raciocínios, não menos absurdos que atrozes, empregados pelos opressores dos negros para exercer a escravidão". Depois, havia referências ao Chevalier de Jaucourt e o seu artigo na Encicloplédia . Em terceiro lugar, surgia o nome do Abade Baudeau, que publicara quatro artigos sobre 0 assunto no mesmo periódico durante o mês outubro de 1766. Em quarto lugar, aparecia Saint-Lambert, autor de um conto - Ziméo -, ao lado do qual estava uma resenha sobre ele, escrita pelo mesmo Du Pont, que expunha um cálculo sobre os custos do trabalho, provando "que o trabalho dos negros escravos é mais caro do que o dos homens livres", o que significava que não há "nenhum interesse, mesmo aparente, em violar todas as leis divinas e humanas, para usar, causando desgraça aos semelhantes, trabalhadores a tão alto preço". Em quinto lugar, estava o Abade Roubaud, que, num artigo publicado no "último volume do Journal do Commerce", mostrou a "injustiça e a barbárie da nossa conduta frente aos escravos negros". Finalmente, as Cartas Africanas... de Butini apareciam como o último texto antiescravista da lista (NEMOURS, Du Pont. "LETTRES AFRICAINES, où Histoire de Phédima et d'Abensar: par Mr. BUTINI”. Éphémérides du citoyen ou Biblio theque Raisonée des Sciences Morales et Politiquest. VIII, 1771, pp.76-77).

${ }^{42}$ Apud DORIGNY, Marcel. "Préface". In MOTYLEWSKI, Patricia. La société française pour l'abolition de l'esclavage. Paris, L'Harmattan, 1998, p.16.

${ }^{43}$ CHAVES. op. cit., pp. 42 e 50.

${ }^{44}$ MACIEL da COSTA. op. cit., p.28.

${ }^{45}$ ANDRADA E SILVA. op. cit., pp. 63 e 69.

${ }^{46}$ Idem, p.70.

${ }^{47}$ LSBOA. op. cit., p.135.

${ }^{48}$ FROSSARD, Benjamin-Sigismond. La cause des esclaves négres et des habitants de la Guinnée. Portée au Tribunal de la Justice, de la Religion, de la Politique; ou Histoire de la traite et de la esclavage des nègres; Preuves de leur illégitimité, Moyens de les abolir sans nuire ni aux Colonies ni aux Colons . Lyon, La Roche, 1789, 2 vol., I, p.18.

${ }^{49}$ Idem, p. 20.

${ }^{50}$ RAY NAL. op. cit., vol. VI, pp. 176-177 e 180. Traduzo aqui o verbo francês adoucir por abrandar . De qualquer modo, essa frase de Raynal deve ser comparada com uma acima citada de José da Silva Lisboa: "é preciso que o jugo seja doce, para não ser inútil".

${ }^{51}$ CONDORCET. "Reflexions sur L'Esclavage des Nègres (1781)”. In O'CONNOR, A. Condorcet e ARAGO, M. F. (org.). Oeuvres de Condorcet. Paris, Firmin Didot Frères, 1847, t. VII, pp. 96 e 106.

${ }^{52}$ FRO SSARD. op. cit, I, p.51. 
${ }^{53}$ Idem, pp. 147 e 294.

${ }^{54}$ Idem, II, p. 02.

${ }^{55}$ RAYNAL op. cit., VI, p.221.

${ }^{56}$ FROSSARD, Benjamin-Sigismond. Benj.-Sig. Frossard à la Convention surl'abolition de la traite des nègres... 12 déc. 1792... Paris, Gueffier, s/d.

${ }^{57}$ RAYNAL op. cit., VI, pp.216-217.

${ }^{58}$ CONDORCET. op. cit., pp.101-102.

${ }^{59}$ ANDRADA E SILVA. op. cit., p.68.

${ }^{60}$ JAMESON, Russel Parsons. Montesquieu et l'esclavage. Étude sur les origines de l'opinion antiesclaviste en France au XVIII éme siècle. New York, Burt Franklim, 1971, p.325.

${ }^{61}$ SMTTH. op. cit., I, p. 428. 